UDC 621.9 .06

S.V.Strutynskyi, Cand. Sc. (Tech.), orcid.org/0000-0001-9739-0399
DOI: $10.29202 /$ nvngu/2018-3/13

The National technical University of Ukraine "Igor Sikorsky Kyiv Polytechnic Institute", Kyiv, Ukraine, e-mail: strutynskyi@gmail.com

\title{
DEFINING THE DYNAMIC ACCURACY OF POSITIONING OF SPATIAL DRIVE SYSTEMS THROUGH CONSISTENT ANALYSIS OF PROCESSES OF DIFFERENT RANGE OF PERFORMANCE
}

Purpose. Complex study of the dynamic processes of positioning of spatial systems with defining their characteristic parameters and developing recommendations on increasing the dynamic accuracy of the system positioning.

Methodology. Theoretical methods for determining the parameters of the positioning processes in the spatial system on the basis of the proposed approach which consists in separating the general process into a number of components with different range of performance. Experimental research methods using high-precision equipment are applied to confirm the reliability of the results of theoretical studies.

Findings. A new approach to the determination of the parameters of the positioning processes of spatial drive systems which explains the possibility of separating the positioning process into components of different ranges and allows determining the parameters of individual components of the process is developed. Processes of different ranges in the mechatronic spatial drive system on the basis of this approach are classified. The configuration of the octahedron has been established with introducing an idealized mechanism for which the analytical relations among the links and the kinematic initial conditions in the spatial drive system during positioning are determined. Calculations are made using the initial conditions and parameters of the process of entering the position of the master drive of the system and the processes of translational and transverse-angular displacement of the platforms are established. Calculations are confirmed by the results of experimental measurements. Recommendations on increasing the dynamic processes of positioning the spatial drive systems are developed on the basis of the conducted research.

Originality. The proposed approach to determining the process of positioning the spatial drive system through time-independent processes with different ranges of performance is fundamentally new. At the same time, new knowledge about the nature of the process parameters in the spatial drive system is obtained. A dynamic model of the drive and methods for its simplification are proposed. The method for determining the initial conditions at the entering the system into the position which means the approximation of the spatial system by the mechanism that corresponds to the octahedron is proposed. The analytical dependencies that are the basis for finding the initial conditions are defined for this mechanism. Models and results of calculations of the process of the drive displacement and the translational and cross-angular displacements of the platform and the established indicators of dynamic accuracy of positioning are introduced.

Practical value. The peculiarities of dynamic positioning processes are established and recommendations on increasing the dynamic accuracy are made by using special vibration damper installed in particular locations of the spatial drive system.

Keywords: spatial system, positioning, using a piston stop, translational displacement, cross-angular displacements, dynamic accuracy

Introduction. Mechatronic spatial drives are the basis of advanced technological equipment, in particular manipulators, industrial robots, and special purpose systems. Spatial drives operate in rigid dynamic modes. Therefore, the study of their dynamic accuracy is important.

The problem is to provide indicators of the dynamic quality of spatial drive systems.

The problem is related to the important scientific and practical tasks of creating efficient process equipment which uses spatial drive systems.

Recent studies and publications provide information on technological equipment based on spatial drive systems $[1,2]$. Much of the research is devoted to the study of dynamic processes in spatial systems [3, 4]. It is pointed out that there are no general approaches to ensuring the necessary dynamic characteristics of such systems $[5,6]$. This is due to the complexity of the dynamic processes occurring in spatial systems.

The dynamic process of positioning is of great importance for spatial systems [7]. At the system positioning

(C) Strutynskyi S.V., 2018 diverse impulse (shock) and vibration processes that determine the performance of the system's dynamic accuracy occur. There are separate studies in this direction in literary sources $[6,7]$. They relate only to certain aspects of the problem and do not describe the process in whole.

There have not been found studies of the dynamic accuracy of positioning in the spatial drive systems yet.

Therefore, the unsolved aspect of the general problem is the determination of dynamic processes positioning of spatial drive systems.

The purpose of the research described in this article is a comprehensive study of the dynamic processes positioning of spatial drive systems through consistent analysis of processes of different range of performance with the definition of their characteristic parameters and the development of recommendations on increasing the dynamic accuracy of the system positioning.

The tasks of the research determined the analysis of the spatial drive system and processes of its positioning, the development of a new approach to the calculation of positioning processes, the calculation of various stages of dynamic positioning processes, their comparison 
with the results of experimental measurements and the development of recommendations on increasing the dynamic accuracy of positioning.

Presentation of the main research. Qualitative analysis of dynamic processes in the spatial drive system. The spatial mechatronic drive system represents a set of devices of different physical nature. The spatial drive system is considered and studied on the basis of the hexapod mechanism which has six drives 1 providing spatial displacement of the platform 2 (Fig. 1) .

Microdisplacement drives are executed in the form of elastic elements $3 \mathrm{i}$ and guided by a special system which includes the electronic part and devices of hydroautomatics. The working processes in separate units of the spatial drive system are significantly different. This leads to a significant difference in the performance of individual elements of the mechatronic system [9].

The platform performs translational displacements in the directions $x, y$ and $z$ and the cross-angular displacements which are characterized by the rotation around the reference axis at the angles $\psi, \theta, \phi$. The rational scheme decision of the drive system is the use of discrete drives in the form of hydraulic cylinders 1,2 and micro-displacements drives aggregated with them 3 [8] (Fig. 2).

The performance of each element of the drive system and the process in it is characterized either by the time of operation or by the characteristic values of the frequency. As the characteristic frequency value is taken the bandwidth of the frequencies of a single element or the characteristic (own) frequency of the dynamic process which proceeds in the element of the mechatronic system [10].

The mechanical part of the mechatronic system, which includes the devices of the hydraulic drive has a bandwidth of the order $1 . . .20 \mathrm{~Hz}$ (Table 1).

The comparison of individual elements of the mechatronic system with respect to speed and bandwidth shows a significant (in several orders) difference between these parameters. Accordingly, the processes given in Table 1 have different scales of performance (Fig. 3).

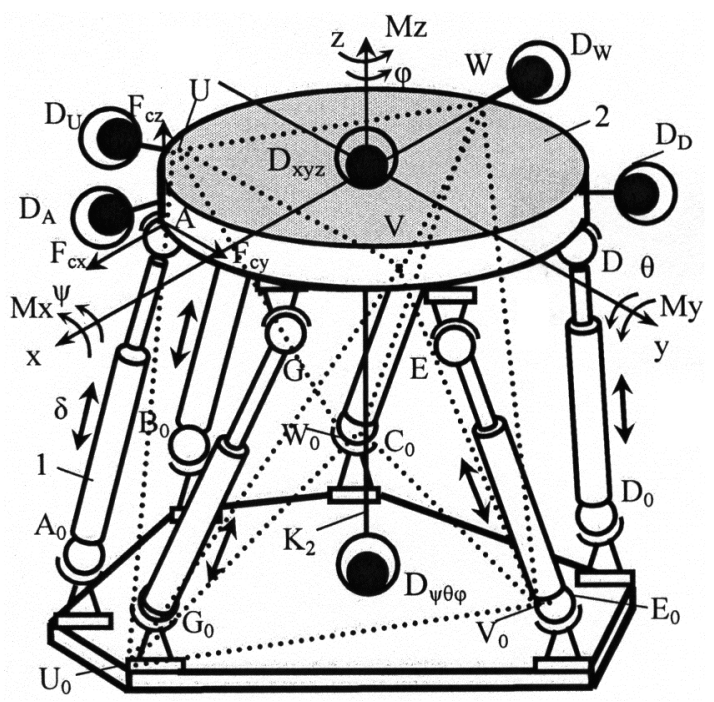

Fig. 1. Constructive scheme of the system of drives for the spatial displacement of the platform

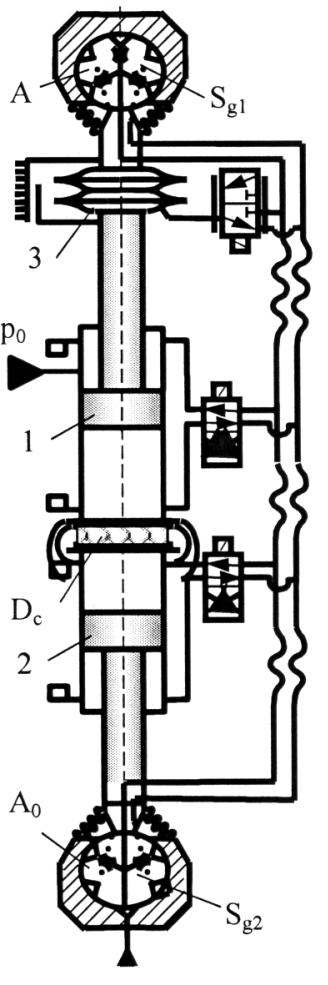

$a$

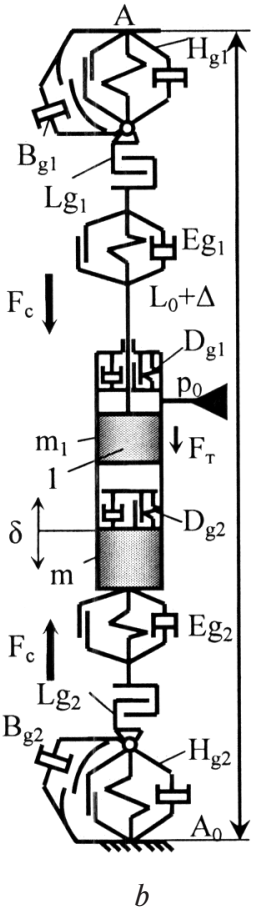

Fig. 2. The variant of implementation of the drive in the form of a hydraulic cylinder and a micro-displacements drive (a) aggregated with it and a dynamic model of the drive (b)

Ranges of performance of the groups of processes considered differ by one to two orders and more. This leads to the need to take into account the interaction of the working processes of individual elements of the mechatronic spatial drive system which have significantly different time range of change.

When setting discrete drives in a fixed position impulse (shock) loads occur associated with the turning

Table 1

Scales of the processes of separate elements of the mechatronic spatial drive systems, their frequency ranges and performance

\begin{tabular}{|c|c|c|c|}
\hline 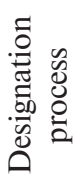 & $\begin{array}{l}\text { Element of the mechatronic } \\
\text { system or process }\end{array}$ & 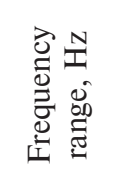 & 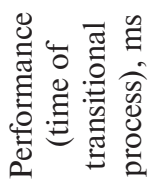 \\
\hline Prt1 & $\begin{array}{l}\text { Hydraulics and of } \\
\text { hydroautomatics }\end{array}$ & $1 \ldots 20$ & $50 \ldots 500$ \\
\hline Prt2 & Electromechanical devices & $10 \ldots 10^{3}$ & $1 \ldots 100$ \\
\hline Prt3 & $\begin{array}{l}\text { The processes of dry friction } \\
\text { and contact deformation }\end{array}$ & $10^{3} \ldots 10^{4}$ & $0.1 \ldots 1$ \\
\hline Prt4 & Vibration processes & $10 \ldots 10^{4}$ & $0.1 \ldots 100$ \\
\hline Prt5 & Wave processes & $10^{3} \ldots 10^{6}$ & $10^{-3} \ldots 1$ \\
\hline Prt6 & Electronic block systems & $10^{6} \ldots 10^{9}$ & $10^{-3} \ldots 10^{-6}$ \\
\hline
\end{tabular}


joints of drives stop. Shock loading generates specific oscillation processes in the spatial drive system. To study oscillation processes, special methods based on the separation of individual processes into groups according to the length of processes or the range of their performance are proposed. The oscillating processes in the spatial drive system in the positioning of the platform are complex and occur in a certain sequence.

In the mechanical part of the spatial drive system (Fig. 1) there are various work processes. Some of them are essentially slow, while others are extremely fast. Slow processes $\left(\operatorname{Pr}_{1}\right)$ are cross-angular oscillations of the platform, and the average speed of processes $\left(\mathrm{Pr}_{2}\right)$ are processes of translational table displacement, while the fast processes $\left(\mathrm{Pr}_{3}\right)$ are the processes of positioning the piston of the cylinder on the stop (Fig. 4).

If the time of the transitional process in the system is taken as a valuation of the dynamic process in the system, then processes of the order $1 \mathrm{~s} ; 0.1 \mathrm{~s} ; 10 \mathrm{~ms}$ will be attributed to different groups with significantly different ranges of performance. It gives grounds for considering the processes sequentially in groups independently of each other. The $\operatorname{Pr}_{3}$ process, the $\operatorname{Pr}_{2}$ and $\operatorname{Pr}_{1}$ processes are considered to have not yet occurred. When regarding the $\operatorname{Pr}_{2}$ process it is considered that the $\mathrm{Pr}_{3}$ process has already occurred and the $\operatorname{Pr}_{1}$ process has not occurred yet. When considering the $\operatorname{Pr}_{1}$ process, the $\operatorname{Pr}_{2}$ and $\operatorname{Pr}_{3}$ processes are considered to have already occurred. To calculate each of the processes it is necessary to determine the initial conditions. They are on the solution of the kinematics problem when the system positioning.

Kinematics of positioning the spatial drive system. To simplify the calculation of the geometry and kinematics of the spatial drive system at its positioning, drive system

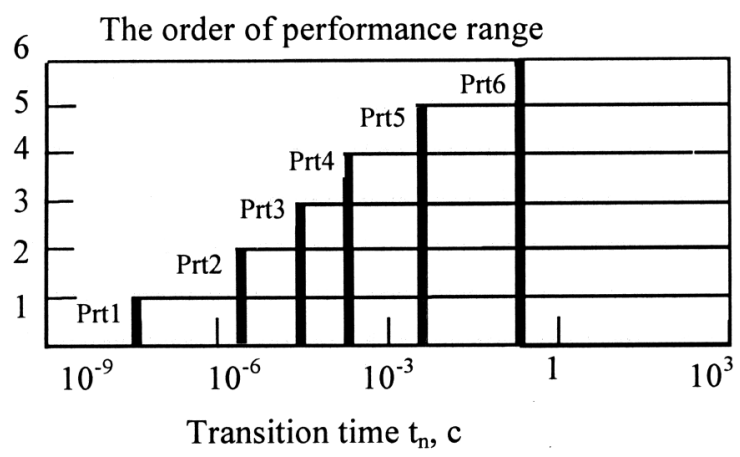

Fig. 3. Performance (transition time) of separate elements of mechatronic drive system

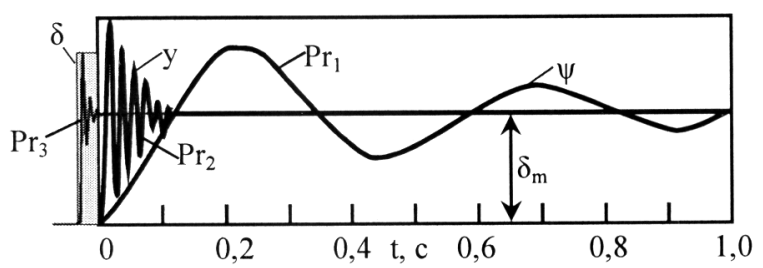

Fig. 4. Transitional processes in the drive system corresponding to the cross-angular displacement of the platform (curve $P r_{1}$ ), the translational displacement of the platform (curve $\mathrm{Pr}_{2}$ ) and positioning of the piston of the cylinder on the stop (curve $\mathrm{Pr}_{3}$ )
$A_{0} A, B_{0} B, \ldots, G_{0} G$ (Fig. 1) is presented as an equivalent hexapodactoedric mechanism with drives of variable length $U_{0} U, U_{0} V, V_{0} V, V_{0} W, W_{0} W, W_{0} U$. It is assumed that the platform moves with the reduction of the master drive $U_{0} U$ (Fig. 5, $a$ ).

In this case, the length of the last five drives remains unchanged. Reducing the length of the master drive to the value $L_{0}=U_{0} U$ the piston of the drive cylinder is set on stop. At the same time the mechanism is positioning and gains a configuration corresponding to an octahedron. For an arbitrary length of the drive $U_{0} U_{1}=L$ the problem of determining the geometry, velocity and acceleration of individual points of the mechanism is solved (Fig. 5,b).Projections of hinge displacement $U$ are found.

From these dependencies (Fig. 5, b) there are projections of hinge speed $U$

$$
\begin{gathered}
V_{U x}=\frac{d x_{U}}{d t}=\frac{\partial x_{U}}{\partial \lambda} \cdot \frac{d \lambda}{d t} ; \quad V_{U y}=\frac{d y_{U}}{d t}=\frac{\partial y_{U}}{\partial \lambda} \cdot \frac{d \lambda}{d t} ; \\
V_{U z}=\frac{d z_{U}}{d t}=\frac{\partial z_{U}}{\partial \lambda} \cdot \frac{d \lambda}{d t} ; \quad \lambda=L / L_{0} .
\end{gathered}
$$

It is accepted that the reduction of the drive $U_{0} U_{1}$ occurs at a constant velocity $V_{0}$. In this case, the length of the drive varies according to the law

$$
L(t)=L_{0}-V_{0} t ; \quad t \leq 0 ; \quad t=-t_{m} \ldots 0 .
$$

For uniform movement of the hinge $U$ we have

$$
\lambda=\lambda(t)=\frac{L(t)}{L_{0}}=1-\frac{V_{0}}{L_{0} t} .
$$

Accordingly $\frac{d \lambda}{d t}=-\frac{V_{0}}{L_{0}}=$ const.

From graphs (Fig. 5, b), we find the values of the projections of the hinge speeds $U$ at $\lambda=1$

$$
V_{U x}=0.7 V_{0} ; \quad V_{U y}=-0.5 V_{0} ; \quad V_{U z}=-0.85 V_{0} .
$$

Similarly, projections of velocities of hinges $V$ and $W$ are found.

The speed field of the platform is defined as a solid body at known velocities of the three points of the platform $U, V, W$. In particular, the projected velocities, the center of the masses of the platform and the projections of the platform rotation speeds are around the reference axis. The velocity values are the initial conditions for calculating the platform movement when positioning

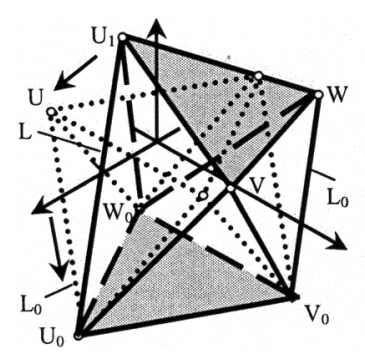

$a$

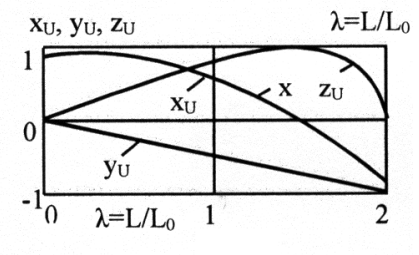

$b$
Fig. 5. The scheme of the hexapodactoedric mechanism when reducing the drive $U_{0} U_{1}(a)$ and the calculation of the coordinate changes of the hinge $U(b)$ 
the $U_{0} U$ drive on the stop. It is assumed that the initial conditions for displacement are zero.

Accordingly at $t=0$

$$
\begin{aligned}
& x_{0}=y_{0}=z_{0}=0 ; \quad V_{x}=V_{0 x} ; \quad V_{y}=V_{0 y} ; \quad V_{z}=V_{0 z} ; \\
& \psi_{0}=\theta_{0}=\varphi_{0}=0 ; \quad \omega_{x}=\omega_{0 x} ; \quad \omega_{y}=\omega_{0 y} ; \quad \omega_{z}=\omega_{0 z} \text {. }
\end{aligned}
$$

The process of positioning a master drive of the spatial system on the stop. The joints $A_{0}$ and $A$ are installed on a fixed base and a movable platform for fastening and rods. The spatial drive mechanism $A_{0} A$ (Fig. 2) is a complex structure which includes a number of series of connected units: hydraulic cylinders and devices.

In this case the dynamic model of the drive has the appearance of a two-mass system $\mathrm{m}_{1}$, with the clearance connections $L_{g 1}, L_{g 2}$ and the elastic-dissipative bonds $H_{g 1}, H_{g 2}, E_{g 1}, E_{g 2}$ ( Fig. 2, b).

The piston of the master drive moves as a result of the supply of fluid under pressure $p_{0}$ into the rod cavity. In this case all equivalent springs are stretched, and the clearances and interstices are selected. There is a static force in the elastic drive system

$$
F_{c}=p_{0} S,
$$

where $p_{0}$ is the pressure in the cavity of the cylinder; $S$ is the area of the rod cavity.

Under the influence of static force there is an extension of the drive by the value

$$
\delta_{m}=\Delta L=F_{c} / C_{e},
$$

where $C_{e}$ is the equivalent rigidity of an elastic drive system which takes into account the rigidity of all components.

When the system is released in position, the piston becomes on the stroke $D_{p 2}$. It is accepted that the piston with the rod and the cylinder body then move as one body with a mass $m_{e}=m_{1}+m_{2}$. At the time of setting the stop the speed of the piston with the stock is $V_{0}$.

After setting on the stop, the speed of the piston with a rod is determined by the pulse theorem [11] and it will be

$$
V_{e}=\frac{V_{0} m_{1}}{m_{1}+m_{2}} .
$$

This speed determines the initial conditions of the oscillations of the dynamic drive system.

$$
A t_{t=0} ; \quad \delta=0 ; \quad \frac{d \delta}{d t}=V_{e}
$$

It is accepted that the positioning of the master drive on the stop is a process infinitely fast compared with the subsequent movement of the platform (Fig. 4).

Accordingly, the process of positioning the stop is determined on the basis of the assumption that there is no influence on the process of the platform movement on it.

A simplified dynamic model of oscillation of the drive is accepted when positioning on the stop as a harmonic second-order oscillator [12] with a mass $m_{e}$, coefficient of resistance $b_{e}$ and rigidity $c_{e}$.

Equation of the drive mass movement is

$$
m_{e} \frac{d^{2} \delta}{d t^{2}}+b_{e} \frac{d \delta}{d t}+c_{e} \delta=F_{c} \cdot 1(t)
$$

The solution of equation (3) under the specified initial conditions according to [12] is defined as

$$
\begin{gathered}
\delta=K+\frac{\sqrt{T^{2} V_{e}^{2}-2 \xi T V_{e} K+K^{2}}}{\sqrt{1-\xi^{2}}} e^{-\frac{\xi}{T} t} \times \\
\times \sin \left[\frac{\sqrt{1-\xi^{2}}}{T} \cdot t+\operatorname{arctg}\left(\frac{\sqrt{1-\xi^{2}}}{\xi-\frac{T V_{e}}{K}}\right)\right],
\end{gathered}
$$

where $K=F_{c} / c_{e} ; T=\sqrt{m_{e} / c_{e}} ; \xi=b_{e} /\left(2 \sqrt{m_{e} c_{e}}\right)$.

The solution (4) determines the change in the length of the drive in dynamics.

The master drive will stop at the end of the oscillation process. Its total reduction at the end of the oscillation process will correspond to the initial static deformation of the drive $\delta_{m}=\delta(t)$ with $t \rightarrow \infty$. Drive oscillations fade over time of $0.008 \ldots 0.01 \mathrm{sec}$.

In the future, the platform will change its position. The final static position of the platform will be determined by the vector $L$ of coordinates with increment $\delta L=\left[\begin{array}{llllll}-\delta_{m} & 0 & 0 & 0 & 0 & 0\end{array}\right]^{T}$. The initial value of the vector $L$ of coordinate is taken to be zero. Accordingly, the platform moves in the final position in accordance with the Jacobian matrix of the hexapodactoedradius mechanism [8] which has the form

$$
\left(m_{i j}\right)=\left[\begin{array}{cccccc}
\frac{\partial x}{\partial L_{1}} & \frac{\partial x}{\partial L_{2}} & \frac{\partial x}{\partial L_{3}} & \frac{\partial x}{\partial L_{4}} & \frac{\partial x}{\partial L_{5}} & \frac{\partial x}{\partial L_{6}} \\
\frac{\partial y}{\partial L_{1}} & \frac{\partial y}{\partial L_{2}} & \frac{\partial y}{\partial L_{3}} & \frac{\partial y}{\partial L_{4}} & \frac{\partial y}{\partial L_{5}} & \frac{\partial y}{\partial L_{6}} \\
\frac{\partial \psi}{\partial L_{1}} & \frac{\partial \psi}{\partial L_{2}} & \frac{\partial \psi}{\partial L_{3}} & \frac{\partial z}{\partial L_{4}} & \frac{\partial z}{\partial L_{5}} & \frac{\partial z}{\partial L_{6}} \\
\frac{\partial \theta}{\partial L_{1}} & \frac{\partial \theta}{\partial L_{2}} & \frac{\partial \theta}{\partial L_{3}} & \frac{\partial \theta}{\partial L_{4}} & \frac{\partial \theta}{\partial L_{5}} & \frac{\partial \theta}{\partial L_{6}} \\
\frac{\partial \phi}{\partial L_{1}} & \frac{\partial \phi}{\partial L_{2}} & \frac{\partial \phi}{\partial L_{3}} & \frac{\partial \phi}{\partial L_{4}} & \frac{\partial \phi}{\partial L_{5}} & \frac{\partial \phi}{\partial L_{6}}
\end{array}\right]=
$$


In this case, the drive $A_{0} A$ corresponds to the fourth column of the matrix. Therefore, the final position of the platform in the static will be determined by the vector of the $\mathrm{x}$-coordinates of the form

$$
\left(x_{i}\right)_{c}=\delta_{m}\left(\begin{array}{llll}
2 \sqrt{3} & -2 / \sqrt{3}-\sqrt{3 / 2} & 0-\sqrt{3 / 2} & 2
\end{array}\right)^{T} .
$$

The transition of the platform to this static position occurs gradually under the action of force from the master drive. Strength varies according to step by step law $F_{c} \cdot 1(t)$. This force has components $F_{c x}, F_{c y}, F_{c z}$, which depends on the angular position of the drive $A_{0} A$ and causes a moment $M \cdot 1(t)$, which acts on a platform and has projections on reference axes $M_{x}, M_{y}, M_{z}$ (Fig. 1). Further displacements of the platform occur under the influence of these force factors.

Parameters of the dynamic movement of the platform when positioning. The displacement of the platform in dynamics as a solid is described by the dynamic translational displacement of the center of mass $O_{t a}$ by the spatial spherical motion of the platform relative to the center of mass [11] according to the dynamic model (Fig. 6).

The differential equations of the translational displacement of the center of mass $\mathrm{O}_{\mathrm{y}}$ are constructed in three directions corresponding to the directions of the main axes of the rigidity of the mechanism. The equations of the dynamics are similar to the equation (3) with the initial conditions defined by the formulas (1). The solution of these equations is determined by formula (4) with the corresponding values of the constants included in the formula.

As a result, the projected displacements of the center of the masses of the platform are found to their finite values $x_{m}, y_{m}, z_{m}$ (Fig. 7).

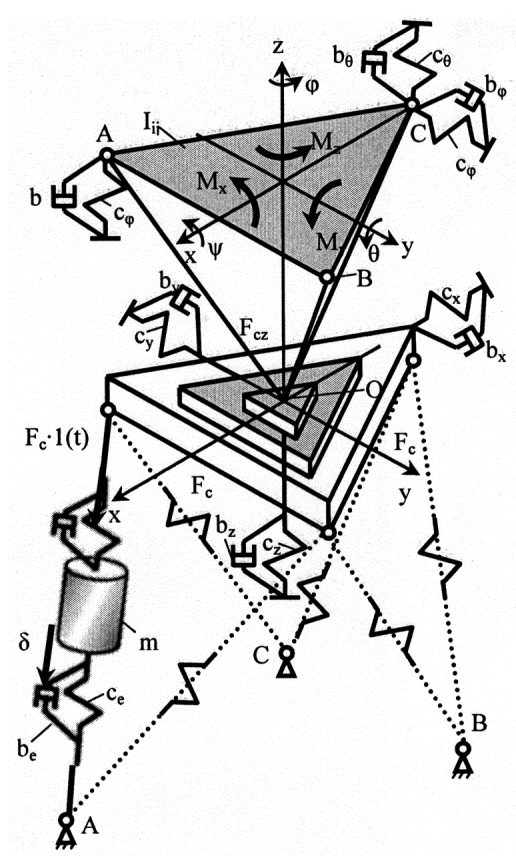

Fig. 6. Dynamic model of the spatial system when it enters the position
Projections of platform center displacements are weakly faded curves of the sinusoidal type. To verify the reliability of the results, experimental measurements of the dynamic displacements of the platform of the prototype of the drive system during the positioning of one of the drives on stop have been conducted. High-sensitivity non-contact laser triangulation meters of the RF603-1012 range with a working range of $2 \mathrm{~mm}$, measuring accuracy of $0.2 \mu \mathrm{m}$ for measurements of the platform movement were used [13] (Fig. 8).

The nominal distance of the meter from the surface of the platform is $10 \mathrm{~mm}$, the discreteness of measurements is $0.5 \mathrm{~ms}$. This allows you to identify the features of the dynamic process of positioning the platform. Comparing the results of calculations with experimental data (Fig. 7), their quantitative and qualitative correspondence follows.

Errors in calculations of displacement amplitudes are within $10 \%$, errors in determination of oscillation periods do not exceed $15 \%$, which is acceptable for this complex spatial drive system. The presence of certain peculiarities of experimentally determined oscillatory processes $F 1$... F4 is explained by nonlinear characteristics of the elements of a dynamic system. Therefore, the accuracy of the proposed mathematical model of the platform positioning process could be considered as satisfactory. By using this model the spatial displacements of the center of the masses of the platform in the process of positioning are determined (Fig. 9).

From the results of calculations, it follows that positioning one of the drives on the stop causes a complex trajectory of the platform center displacement from the point $O_{1}$ to the point $O_{2}$. There is a pulsating motion of the platform when it is released into position. Spatial mass center displacements occur within the boundary of theellipsoidal area $E_{1}, E_{2}$.
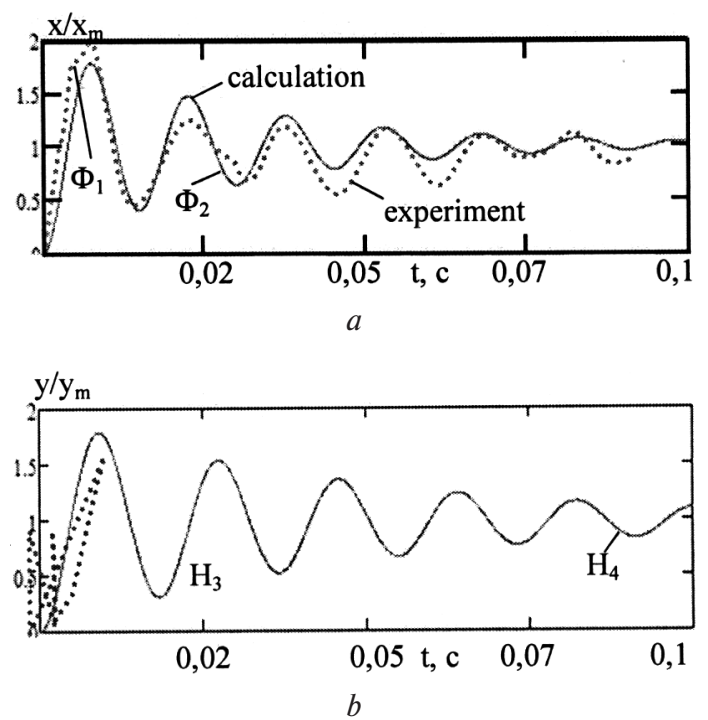

Fig. 7. Comparison of the calculated (solid curves) and experimentally determined (dashed curves) displacements of the center of the platform in the direction $x$ (a) and $y$ (b) 


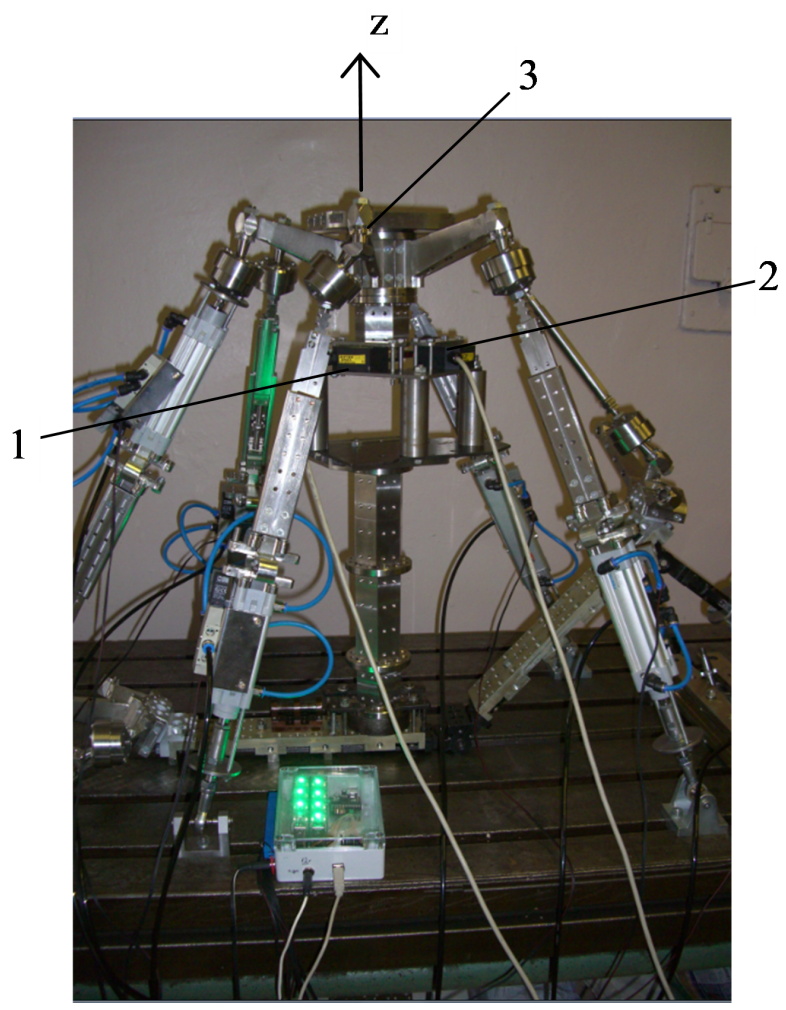

Fig. 8. Installation of laser meters 1, 2 of the platform displacement 3 when determining the processes of its dynamic positioning
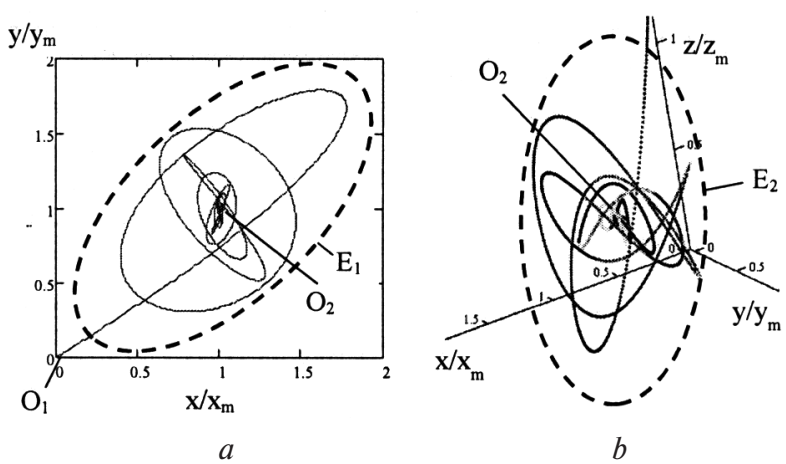

Fig. 9. Calculated platform mass center displacement when positioning:

$a-i$ s the trajectory of displacement in the plane oxy; $b-i s$ the spatial trajectory of the platform displacement

Platform mass center displacement occurs within a time interval of about 0.1 seconds. Accordingly, the performance of this process is an order lower than the performance of the oscillation process in the master drive.

The process of cross-angular displacements of the platform is slower. It is determined by numeral integrating of the equations of the spherical motion of the platform according to a specially designed procedure.

In the projections on the reference axis the equation of the spherical motion of the platform as a solid [14] has the form

$$
\left\{\begin{array}{l}
\frac{d L_{x}}{d t}+\omega_{y} L_{z}-\omega_{z} L_{y}=M_{x} \\
\frac{d L_{y}}{d t}+\omega_{z} L_{x}-\omega_{x} L_{z}=M_{y} \\
\frac{d L_{z}}{d t}+\omega_{x} L_{y}-\omega_{y} L_{x}=M_{z}
\end{array}\right.
$$

where $M_{x}, M_{y}, M_{z}$ are projections of the main moment of forces acting on the platform, $\omega_{x}, \omega_{y}, \omega_{z}$ are projections of the angular velocity of the platform, $L_{x}, L_{y}, L_{z}$ are projections of the momentum amount (kinetic moment).

The kinetic moment equals the product of the tensor of the inertia of the platform $\left(I_{i j}\right)$ on the vector of angular velocity.

In projections on reference axes

$$
\begin{aligned}
& L_{x}=I_{x x} \omega_{x}-I_{x y} \omega_{y}-I_{z x} \omega_{z} ; \\
& L_{y}=-I_{x y} \omega_{x}+I_{y y} \omega_{y}-I_{y z} \omega_{z} ; \\
& L_{z}=-I_{z x} \omega_{x}-I_{z y} \omega_{y}+I_{z z} \omega_{z},
\end{aligned}
$$

where $I_{x x}, I_{y y}, I_{z z}, I_{x y}, I_{x z}, I_{y z}$ are the components of the tensor of inertia of the platform defined in the a frame of reference $x, y, z$.

The inertia tenser is symmetrical, that is why $I_{y x}=I_{x y}$, $I_{y z}=I_{z y}, I_{z x}=I_{x z}$.

The equations of spherical motion (6) are used to develop a procedure for numerical calculations of the cross-angular displacements of the platform. To do this, the system of differential equations (6) by integrating in time is reduced to a system of three integral equations

$$
\begin{aligned}
& L_{x}=L_{x 0}+\int_{0}^{t}\left(M_{x}-\omega_{y} L_{z}+\omega_{z} L_{y}\right) d t ; \\
& L_{y}=L_{y 0}+\int_{0}^{t}\left(M_{y}-\omega_{z} L_{x}+\omega_{x} L_{z}\right) d t ; \\
& L_{z}=L_{z 0}+\int_{0}^{t}\left(M_{z}-\omega_{x} L_{y}+\omega_{y} L_{x}\right) d t,
\end{aligned}
$$

where $L_{x 0}, L_{y 0}, L_{z 0}$ are initial values of the projection of kinetic moment. The initial values of the projections of the kinetic moment are based on the dependences (7), in which the values of the initial angular velocities (2) are set.

A structural mathematical model of cross-angular displacements of the platform has been developed on the basis of equations (8) (Fig. 10).

The model includes the Par block in which the kinematic initial conditions are given (2). The moments of the forces acting on the platform are found in magnitude of the static load $F_{c}$, acting on the hinge A (Fig. 1) and is calculated in the block Moment (Fig. 10). The solution of the integral equations (8) is carried out in the Kinetmoment block and the calculation of the angular velocities of the platform is carried out by the VectorOmega 
block. The solution of equations (7) in this block is carried out in relation to the corresponding angular velocity projections. In particular, the projection $\omega \chi$ is from the first equation, $\omega \mathrm{u}$ from the second one, and $\omega \mathrm{z}$ from the third one. The components of the inertia tensor necessary for solving the equations are formed in the block of the TenzIner model. Through integrating the angular velocity values, the angles of the platform rotation relative to the reference axes are found. As a result of calculations, transitional processes of cross-angular displacements have been found (Fig. 11).

Methods of harmonic and spectral analysis are used to study oscillatory platform processes [15]. As a result of the calculations, it has been established that the oscillations of the platform $\psi$ around the axis $\mathrm{x}$ are smoothly damped with a variation of about 2.5 oscillations during the transient process, which is about $1 \mathrm{sec}$. Thus, the range of the performance of this process is an order higher than the performance of the process of platform mass center displacement (Fig. 4).

Overregulation of the process is about $60 \%$ (Chart 11).

Cross-angular displacements of the platform around the $\mathrm{z}$ axis (curve $\varphi$ ) are more pronounced.

The maximum overregulation is about $25 \%$, a number of full vibrations is about 1.2 and the time of the

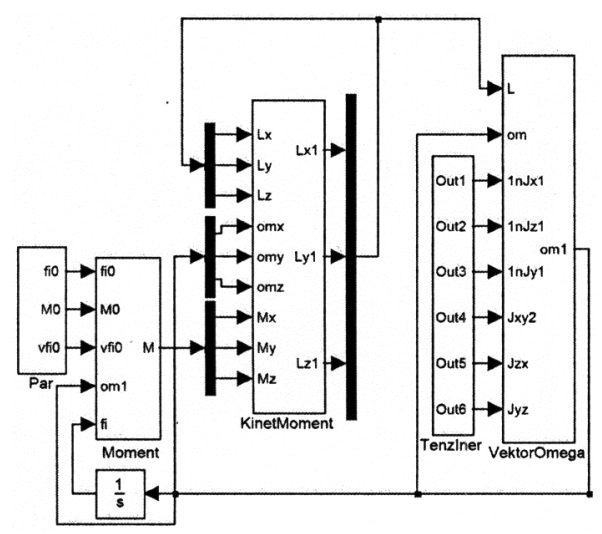

Fig. 10. General structural mathematical model of crossangular displacements of the platform

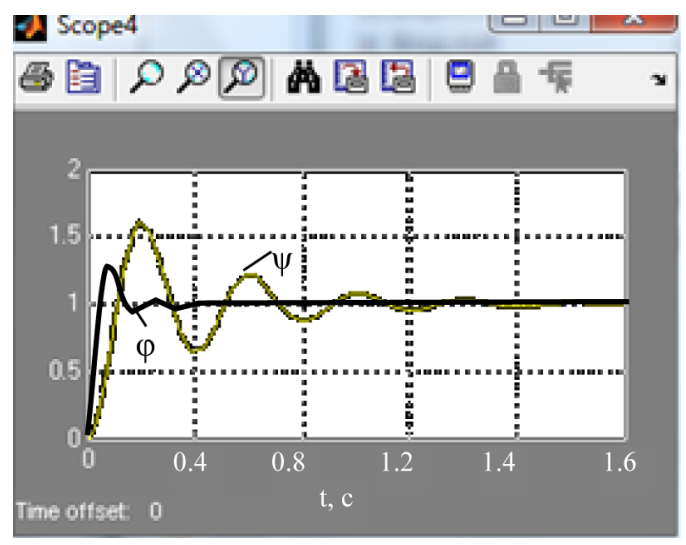

Fig. 11. Calculated cross-angular displacements of the platform around the $x$ axis (curve $\psi$ ) and around the $z$ axis (curve $\varphi$ ) transition process is $3 \ldots 4$ times less than that with oscillations around the axe $\mathrm{x}$.

Cross-angular displacements of the platform lead to the displacement of the hinge A in the plane yoz (Fig. 4). The existence of significant influence of the cross-angular oscillations of the platform on the hinge displacements is established. These displacements have a spiral character and are completed when the platform enters the position (Fig. 12).

In general, the hinge displacement occurs within the ellipsoidal area $E_{3}$.

On the basis of calculation of parameters of the positioning process and experimental research, recommendations on increasing the dynamic accuracy of the drive system have been developed.

Recommendations on increasing the dynamic accuracy of the positioning spatial drive system. Taking into account that general dynamic perturbation within system positioning pulse loads in the master drive, it is recommended to make change in the process of positioning the piston on the stop. Therefore, it is proposed to use a special damper for oscillations of the cylinder body Dc (Fig. 2, a). The use of brake devices $\mathrm{Dg}_{1}$ and $\mathrm{Dg}_{2}$ which provide a reduction of shock loads when positioning the piston 1 on the stop (Fig. 2, $b$ ) is effective.

The radical method for reducing impulse loads at cylinder positioning is the application of spherical hydrostatic joints $S_{g 1}$ and $S_{g 2}$ (Fig. 2, $a$ ). A layer of lubricant between spherical surfaces reduces the intensity of impulse loads and changes the nature of the piston braking process $\delta(t)$ from the oscillating $\Delta L$ (Fig. 4) to the aperiodic or near-aperiodic. In the case of intense pulsed loads the characteristics of the hinges become non-linear and there are nonlinear forces of mixed friction $B_{g 1}$ and $B_{g 2}$ (Fig. 2,b). Non-linear forces of friction substantially smooth the process of the cylinder piston positioning.

In order to reduce the intensity of the oscillatory processes of the translational displacement of the platform, it is recommended to use inertial vibration dampers with a powerful permanent magnet in the shape of a ball that is placed in the spherical cavity of the damper

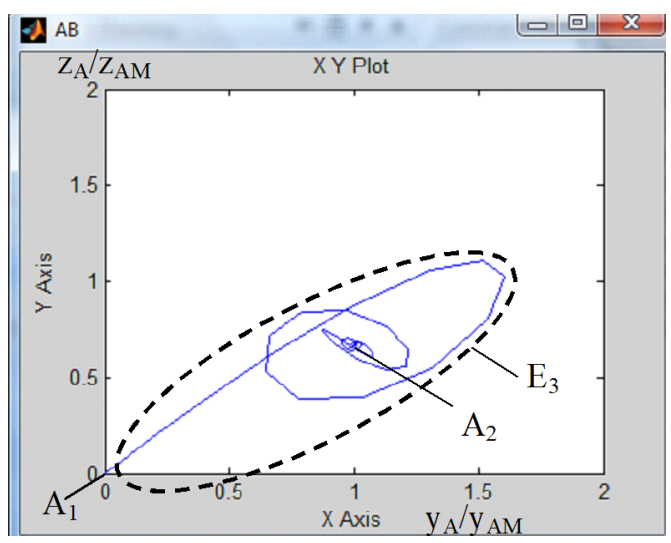

Fig. 12. Calculated displacements of the hinge $A$ in the yoz plane are due to the cross-angular oscillations of the platform 
housing filled with a ferromagnetic fluid. Permanent magnets, which provide the equilibrium positions of the magnetic sphere are located on the periphery of the case. $D_{x y z}$ damper installed in the center of the platform mass (Fig. 1) provides a reduction of the forward oscillations of the platform. In this case the trajectory of the spatial displacements of the platform will be substantially smoothed (Fig. 9).

In order to reduce the intensity of cross-angular oscillations of the platform relative to the axes $x$ and $y$ it is recommended to use the $D_{\psi \theta \phi}$ damper mounted on the arm $K r$ (Fig. 1). The length of the arm should be as high as possible to ensure effective damping of low frequency cross-angular oscillations of the platform.

If the damping of the cross-angular oscillations of the platform relative to the three axes $x, y$ and $z$ is necessary, it is recommended to use three damper DU DW installed uniformly along the perimeter of the platform. These three dampers will also provide a reduction in the intensity of the dynamic translational displacement of the platform. Therefore, three dampers are recommended as a base damping system. The complicated option of the base system is the use of six dampers DA, ..., $\mathrm{DD}$, each of which is installed in close proximity to the hinge of the corresponding drive.

Conclusions. A new approach to determining the parameters of dynamic processes of positioning spatial drive systems is proposed. It consists in the division of processes into separate groups with different range of performance and it is effective and allows calculating individual dynamic processes in the system independently of each other.

The kinematic initial conditions of the spatial drive system should be determined by the simplified geometric scheme of the spatial system in the shape of an octahedron. For this scheme, geometric and kinematic relationships are established in the form of simple analytical dependencies that determine all the necessary initial conditions of the positioning process.

It is established that the process of master drive positioning on the stop is an infinitely fast process compared with the platform displacement and initiates the process of translational displacements of the platform, whose range of performance is an order slower than the process of positioning the drive on the stop. The process of cross-angular displacements of the platform, which is an order slower than the process of translational displacement of the platform, is initiated.

In order to reduce the intensity of oscillation processes of positioning the spatial drive system it is recommended to use dampers of oscillations of cylinder cases, piston braking devices at the end of the stroke, hydrostatic hinges in drives and special inertial dampers of spatial oscillations of the platform.

\section{References.}

1. Mansoor Alghooneh, Christine Qiong $\mathrm{Wu}$ and Masoumeh Esfandiari, 2016. A Passive-Based Physical Bipedal Robot With a Dynamic and Energy-Efficient Gait on the Flat Ground. Journal Transactions on Mechatronics, 21(4), pp. 1977-1984.
2. Baoquan Li, Yongchun Fang, Guoqiang Hu and Xuebo Zhang, 2016. Model-Free Unified Tracking and Regulation Visual Servoing of Wheeled Mobile Robots. Journal Sensors and Actuators A: Physical, IEEE Transactions on Control Systems Technology, 24(4), pp. 1328-1339.

3. Pavlenko, I.I., 2016. Industrial works and RTK. Kropivnitsky: Publisher Lysenko V.F.

4. Amin Ghadami, 2016. Bifurcation Forecasting for Large Dimensional Oscillatory Systems: Forecasting Flutter Using Gust Responses. Journal of Computational and Nonlinear Dynamics, 11(6), 8 pages. DOI: 10.1115 / 1.4033920 .

5. Daisuke Kono, Syuya Nishio, Iwao Yamaji and Atsushi Matsubara, 2015. A method for stiffness tuning of machine tool supports considering contact stiffness. International Journal of Machine Tools and Manufacture, 90, pp. 50-59. DOI: 10.1016/j.ijmachtools.2015.01.001. 6. Georg Nawratil and Josef Schicho, 2015. Self-motions of pentapods with linear platform. Robotica, Cambridge University Press, 29 pages. DOI: 10.1017/ S0263574715000843.

7. Sebastien Briot and Wisama Khalil, 2015. Dynamics of Parallel Robots: From Rigid Bodies to Flexible Elements. Springer International Publishing Switzerland.

8. Heisel, U., Strutinskiy, S., Sidorko, V., Filatov, Yu. and Storchak, M., 2011. Development of controllable spherical fluid friction hinges for exact spatial mechanisms. Production Engineering, 5, pp. 241-250. DOI: 10.1007/s11740-010-0291-9.

9. Strutynskyi, V. B., Hurzhiy, A.A., Kolot, O. V. and Polunichev, V. E., 2016. Determination of development grounds and characteristics of mobile multi-coordinate robotic machines for materials machining in field conditions. Naukovyi Visnyk Natsionalnoho Hirnychoho Universytetu, 5, pp. 43-51.

10. Andreas Müller and Zdravko Terze, 2014. The significance of the configuration space Lie group for the constraints at is faction in numerical time integration of multi body systems. Mechanism and Machine Theory, 82, pp. 173-202. DOI: 10.1016/j.mechmachtheory.2014.06.014.

11. Dashchenko, A. F., Kolomieets, L. V. and Svinarev, Yu. N., 2015. Theoretical Foundations of Engineering Mechanics. Odessa: Publisher "Pluton".

12. István Kecskés, Ervin Burkus, Fülöp Bazsó and Péter Odry, 2015. Model validation of a hexapod walker robot. Cambridge University Press.

13. Strutynskyi, S. V. and Hurzhii, A. A., 2017. Definition of vibro displacements of drive systems with laser triangulation meters and setting their integral characteristics via hyper-spectral analysis method. Naukovyi Visnyk Natsionalnoho Hirnychoho Universytetu, 1, pp. 75-81. 14. Jaime Gallardo-Alvarado, Ramon Rodriguez-Castro, Martin Caudillo-Ramirez and Luciano PerezGonzalez, 2015. An Application of Screw Theory to the Jerk Analysis of a Two-Degrees-of-Freedom Parallel Wrist. Robotics, 4, pp. 50-62.

15. Ho-Seung Jeong and Jong-Rae Cho, 2016. Optimal design of head expander for a lightweight and high frequency vibration shaker. International Journal of Precision Engineering and Manufacturing, 17(7), pp. 909-916. 


\section{Визначення динамічної точності позиціонування просторової системи приводів послідовним аналізом процесів різного масштабу швидкодії}

\section{С. В. Струтинський}

Національний технічний університет України „Київський політехнічний інститут імені Ігоря Сікорського“, м. Київ, Україна, e-mail: strutynskyi@gmail.com

Мета. Комплексне дослідження динамічних процесів позиціонування просторових систем приводів із визначенням їх характерних параметрів i розробкою рекомендацій щодо підвищення динамічної точності позиціонування системи.

Методика. Теоретичні методи визначення параметрів процесів позиціонування у просторовій системі на основі запропонованого підходу, що полягає в розділені загального процесу на ряд складових з різними масштабами швидкодії. Застосовані експериментальні методи досліджень з використанням високоточної апаратури, що служать для підтвердження достовірності результатів теоретичних досліджень.

Результати. Розроблено новий підхід до визначення параметрів процесів позиціонування просторових систем приводів, що обгрунтовує можливість розділення процесу позиціонування на складові різних масштабів і дозволяє визначити параметри окремих складових процесу. На основі даного підходу класифіковані процеси різних масштабів у просторовій системі приводів. Шляхом уведення ідеалізованого механізму з конфігурацією, що відповідає октаедру, і для якого встановлені аналітичні співвідношення між ланками, визначені кінематичні початкові умови у просторовій системі приводів при позиціонуванні. Із використанням початкових умов виконані розрахунки й встановлені параметри процесу виходу в позицію ведучого привода системи та процесів поступального й поперечно-кутового переміщення платформи. Розрахункові дані підтверджені результатами експериментальних вимірів. На основі проведених досліджень розроблені рекомендації щодо підвищення динамічної точності позиціонування просторо просторової системи приводів.

Наукова новизна. Принципово новим є запропонований підхід до визначення процесу позиціонування просторової системи приводів у вигляді незалежних у часі процесів із різними масштабами швидкодії. При цьому одержані нові знання щодо характеру параметрів процесів у просторовій системі приводів. Запропонована динамічна модель привода та методи ії спрощення. Новою є запропонована методика визначення початкових умов при виході системи в позицію, що полягає в апроксимації просторової системи механізмом, який геометрично відповідає октаедру. Для даного механізму визначені аналітичні залежності, що $€$ основою для знаходження початкових умов.
Новими є моделі та результати розрахунків процесу переміщення привода й поступальних і поперечно-кутових переміщень платформи, встановлені показники динамічної точності позиціонування.

Практична значимість. Встановлені особливості динамічних процесів позиціонування та розроблені рекомендації щодо підвищення динамічної точності шляхом застосування спеціальних демпферів коливань, встановлених у характерних місцях просторової системи приводів.

Ключові слова: просторова система, позиціонування, постановка поршня на упор, поступальні переміщення, поперечно-кутові переміщення, динамічна точність

\section{Определение динамической точности позиционирования пространственной системы приводов последователыным анализом процессов разного масштаба быстродействия}

\section{С. В. Струтинский}

Национальный технический университет Украины „Киевский политехнический институт имени Игоря Сикорского“, г. Киев, Украина, e-mail: strutynskyi@gmail.com

Цель. Комплексное исследование динамических процессов позиционирования пространственных систем приводов с определением их характерных параметров и разработкой рекомендаций по повышению динамической точности позиционирования системы.

Методика. Теоретические методы определения параметров процессов позиционирования в пространственной системе на основе предложенного подхода заключаются в разделении общего процесса на ряд составляющих с различными масштабами быстродействия. Применены экспериментальные методы исследований с использованием высокоточной аппаратуры, которые служат для подтверждения достоверности результатов теоретических исследований.

Результаты. Разработан новый подход к определению параметров процессов позиционирования пространственных систем приводов, который обосновывает возможность разделения процесса позиционирования на составляющие различных масштабов и позволяет определить параметры отдельных составляющих процесса. На основе данного подхода классифицированы процессы различных масштабов в пространственной системе приводов. Путем введения идеализированного механизма с конфигурацией, соответствующей октаэдру, для которого установлены аналитические соотношения между звеньями, определены кинематические начальные условия пространственной системы приводов при позиционировании. С использованием начальных условий выполнены расчеты и установлены параметры процесса выхода в пози- 
цию ведущего привода системы и процессов поступательного и поперечно-углового перемещения платформы. Расчетные данные подтверждены результатами экспериментальных измерений. На основе проведенных исследований разработаны рекомендации по повышению динамической точности позиционирования просторно пространственной системы приводов.

Научная новизна. Принципиально новым является предложенный подход к определению процесса позиционирования пространственной системы приводов в виде независимых во времени процессов с различными масштабами быстродействия. При этом получены новые знания о характере параметров процессов в пространственной системе приводов. Предложена динамическая модель привода и методы ее упрощения. Новой является предложенная методика определения начальных условий при выходе системы в позицию, которая заключается в аппроксимации пространственной системы механизмом, который геометрически соответствует октаэдру. Для данного механизма опре- делены аналитические зависимости, которые являются основой для нахождения начальных условий. Новыми являются модели и результаты расчетов процесса перемещения привода и поступательных и поперечно-угловых перемещений платформы и установлены показатели динамической точности позиционирования.

Практическая значимость. Установлены особенности динамических процессов позиционирования и разработаны рекомендации по повышению динамической точности путем применения специальных демпферов колебаний, установленных в характерных местах пространственной системы приводов.

Ключевые слова: пространственная система, позиционирование, постановка поршня на упор, поступательные перемещения, поперечно-угловые перемещения, динамическая точность

Рекомендовано до публікації докт. техн. наук О.В.Шевченком. Дата надходження рукопису 26.04.17. 